\title{
Kathleen Walker Meikle, Medieval Pets. The Boydell Press, Woodbridge, 2012, 179 páginas. ISBN: 9781843837589.
}

\author{
Dolores Carmen Morales MuñIz \\ Laboratorio de Arqueozoología de la Universidad Autónoma de Madrid
}

Los estudios sobre Zoohistoria medieval han proliferado de manera importante en los últimos años, particularmente fuera de nuestras fronteras, lo que permite disponer actualmente una importante bibliografía sobre el tema. Sin embargo, dentro de la amplitud que supone el estudio hombre-animal, uno de los aspectos más deficiente o prácticamente nada tratado es el de los animales de compañía.

El libro objeto de esta recensión acaba por cubrir esa carencia. Carencia que, para el caso de la España medieval, he procurado paliar con un pequeño trabajo divulgativo aun en prensa ${ }^{1}$.

Medieval Pets, sin embargo, no es un trabajo precisamente pequeño y tampoco divulgativo. Es un espléndido estudio académico escrito por una investigadora especialista en animales y medicina medieval que muy recientemente ha publicado dos pequeñas monografías sobre perros y gatos ${ }^{2}$.

Etimológicamente el término inglés pet remite al verbo mimar, o acariciar así como a un adjetivo: mimado, favorito, y también, domesticado. El Diccionario de Oxford en 1539 definía el término pettis, como un animal domesticado o domado, conservado por placer o compañía, es decir que no se comía y se le daba un nombre.

El libro, como explica su contraportada, refleja la relación hombre animal desde el ángulo menos convencional. Y es que los animales de compañía, lo que hoy denominamos mascotas, ocupaban el nivel de relación más estrecho con el hombre por el mero hecho del placer que producía su compañía. Y esto no deja de ser una excepción en el trato recibido por la mayoría de los animales cuya presencia se explica en la vida del hombre en su calidad de propiedad de aquel, es decir, por motivos de explotación económica (dieta, ganadería, caza, pesca, carga y transporte, comercio, industrias...).

\footnotetext{
Perros y Pájaros: las mascotas en la España medieval aceptado para su publicación en la revista $M E$ DIEVAL Arqueología, Historia y Viajes, Editorial Gram.

2 K. Walker Meikle ha publicado en The British Library dos pequeños libros monográficos muy recientes cuyo denominador común, además de un interesante contenido, es la inclusión de espléndidas imágenes de los animales objeto del estudio. Medieval Cats, se publicó en 2011 y en mayo de 2013 lo hizo Medieval Dogs.
} 
Las especies animales que tendrían la consideración de mascotas serían, básicamente, las domésticas siendo la más habitual el perro seguido del gato pero también fueron apreciados como animales de compañía, los conejos, las ardillas, y los monos. De entre las aves destacaban las cantoras pero también las exóticas caso de loros, cotorras o papagayos. Pero las diversas fuentes medievales también reflejan el interés por la compañía de especies tan curiosas como los tejones acollarados, de donde se deduce su posible condición de domesticados y mascotas, y que son reproducidos en una de las láminas del libro de Walker Meikle concretamente en el Autoretrato de Giovanni Antonio Bazzi (il Sodoma) dentro del fresco sobre la vida de San Benito (Abadía de Monte Oliveto en Asciano, Toscana). En este contexto hay que recordar, en cuanto a mascotas curiosas, a la comadreja (doeciña) protagonista de la Cantiga 354 de de Alfonso $\mathrm{X}$ en donde encontramos la clave de lo que distingue a un animal de compañía y no es otra que "el amor que su dueño le profesaba".

Profusamente documentado, el libro de K. Walker ha utilizado toda la tipología de fuentes escritas o documentales así como materiales para escribir el trabajo incluyendo, en el caso de estas últimas, algunas referencias arqueozoológicas. Estas últimas tendrían un alcance limitado, dado que la información arqueozoológica no discrimina si se trata de un animal de compañía salvo por el contexto (especie exótica, p.e.) si bien los huesos sin dañar podrían indicar que nos encontramos ante un ejemplar para la compañía. Lo que sí parece claro es que los huesos parecen revelar la existencia de animales que, como las cotorras, sólo tendrían ese fin. Otras fuentes materiales remiten al estudio de los accesorios de los animales de compañía que proporcionan una muy interesante información fueran jaulas, cojines o collares en donde también se plasmaban las armas de sus amos.

Seguramente son las fuentes artísticas e iconográficas las que, además de proporcionar la información necesaria, serían las más agradecidas a la hora de redactar el trabajo, dado que reflejan a los diferentes animales de compañía en miniaturas de manuscritos, tumbas, vidrieras, objetos cotidianos o cuadros. De todas las imágenes, de muy diversa procedencia que ilustran el contenido se destacan las láminas a color con nueve reproducciones, mientras las ilustraciones en blanco y negro llegan a una veintena.

La tipología de las más de cien fuentes publicadas utilizadas por la autora es muy variada incluyendo crónicas, normativa legal, escritos eclesiásticos y religiosos, géneros literarios, documentación económica y fiscal, compendios médicos etc. Y es que no existen fuentes sobre animales exclusivamente salvo literatura específica caso de tratados cinegéticos o los Bestiarios. Todos los datos deben entresacarse y esto convierte a la especialidad zoohistórica en un trabajo extremadamente laborioso no siempre valorado.

El trabajo está documentado con una erudita y reciente bibliografía citada, junto con las fuentes escritas, en cientos de notas recogidas en un apartado de cuarenta hojas. Asimismo se añade, tras la lista bibliográfica, una selección de ocho páginas de Internet (websites) prácticamente casi todas ellas de origen británico. Todo esto produce un trabajo de extraordinaria solidez y rigurosidad plasmado en un interesante y ameno contenido de fácil lectura. 
Hagamos ahora un breve resumen. Dividido en seis capítulos con un reducido prefacio y una conclusión, los capítulos abarcan todos los aspectos posibles del tema: discusión sobre lo que es una mascota (capítulo 1), cómo se conseguían (capítulo 2), sus cuidados y bienestar (capítulo 3) y la convivencia con el animal (capítulo 4). Los dos últimos capítulos analizan a las mascotas en la iconografía (capítulo 5) y en la literatura (capítulo 6).

En la Introducción la autora subraya como el animal de compañía rompía las fronteras del status entre animales y humanos al ser tratados como los segundos y compartir su espacio. K. Walker Meikle centra su estudio, sobre todo, en los animales que se conservaban en el interior de los edificios fueran hogares, monasterios, o castillos (indoors). Los propietarios que preferentemente tenían mascotas eran los clérigos, las mujeres y también los dedicados al estudio y a la erudición (scholars). Las mascotas más habituales, como hemos citado, eran los perros y los gatos pero también los monos, los pájaros cantores, los hurones -hoy tan de moda- las ardillas y los conejos. De todos ellos los perros eran los favoritos, sobre los que Hildegarda de Bingen escribía que eran odiados por el demonio por su lealtad hacia los humanos. Y aunque los gatos - los preferidos de los clérigos- les seguían en preferencia, su evolución fue bien distinta al sufrir persecución y crueldad por su asociación con brujas, supersticiones y herejías antes de ser definitivamente aceptados.

Considerados como auténtica medicina para la soledad y la melancolía la posesión de mascotas era fomentada por la literatura médica. La hagiografía es una interesante fuente para el conocimiento de los animales de compañía: los santos amaban a los animales porque eran parte de la creación divina, siendo esto particularmente visible en los franciscanos. Algunos animales formaban parte de un atributo del santo, caso del perro de san Roque tantas veces reflejado y que ha seleccionado en una de las láminas del libro concretamente procedente de un Libro de Horas holandés.

El segundo capítulo repasa la forma de hacerse con los animales de compañía (regalo, compra, criaderos...) que, en el caso de animales exóticos, suponía el desembolso de una importante suma no exenta de complicaciones.

El capítulo tercero se ocupa de los cuidados a los animales caso de la alimentación que podía llegar a la extravagancia como se afirma de los monos del obispo de Durham (1274-83) que les daba almendras molidas en cucharillas de plata.

La convivencia con las mascotas (capítulo 4) no siempre era fácil seguramente porque podía ser muy continua. Los animales estaban en todas partes también en lugares sagrados caso de monasterios y conventos, fuera y dentro de las casas, universidades y lugares de estudio y, naturalmente, se desplazaban con sus amos también a la hora de viajar.

En los capítulos quinto y sexto se contiene quizás la parte más fácil de escribir por la mayor abundancia de fuentes o, al menos, la mayor facilidad para reflejarlas ${ }^{3}$. Se repasa, pues, los animales de compañía acompañando, y valga la redundancia, a sus amos en

En http://www.ucm.es/bdiconografiamedieval/rdim se recogen excelentes trabajos sobre iconografía medieval, algunos sobre animales,. Un ejemplo acabado es el de Mónica A. Walker Vadillo, Los simios vol. 5, núm. 9 pp. 63-77, publicado en 2013 http://www.ucm.es/bdiconografiamedieval/numero-9 
sus retratos como patrones en los Libros de Horas hasta colocados a sus pies en las efigies funerarias. En definitiva la mascota acompañaba a su amo en las más variadas actividades: estudiando, rezando y durmiendo.

El capítulo de la literatura, último del libro, repasa la presencia de las mascotas en los géneros literarios, un aspecto de la actividad zoohistórica que, como en el caso anterior, contiene abundantes referencias. Los géneros son variados: el amor cortés, los exempla, poesía, épica y elegías. Un ejemplo notable de estas últimas remite a una singular mascota: Annone, el elefante blanco de León X. El animal había llegado a Roma como parte de la delegación del rey de Portugal Manuel I (1469-1521) que se lo ofreció como presente al Pontífice, en la tradición de entregar animales exóticos como regalos. León $\mathrm{X}$ le tomó gran aprecio, hizo que Rafael le reflejara en un fresco y él mismo, cuando el animal murió, le escribió un epitafio que Filippo Beroaldo puso en hexámetros. El poeta ya tenía cierta experiencia porque había compuesto el epitafio para Aurea, el perro de la condesa Isabel de Este.

En las conclusiones la autora no deja de sorprenderse al comprobar como, en una sociedad tan antropocéntrica como la medieval, el animal se había elevado a la categoría de compañero. Porque, además de la visión estereotipada de tener animales como signo de status o entretenimiento, se llegó a la conclusión que el beneficio de ese trato favorecía no sólo al animal aun más, al propietario. Santo Tomás subrayaba que mostrar compasión hacia los animales provocaba compasión hacia los humanos.

En definitiva, el libro de Kathleen Walker Meikle no es sólo una gran aportación a la Zoohistoria. Es un trabajo que completa nuestra visión de la relación entre el hombre y el animal desde una perspectiva tan apasionante como el papel jugado por las mascotas en la vida cotidiana de los hombres y, más aun, de las mujeres de la Edad Media. 